\title{
PENGARUH FAKTOR-FAKTOR PELAKSANAAN PP 46 TAHUN 2013 TERHADAP KEPATUHAN WAJIB PAJAK UMKM (Studi Kasus UMKM Pusat Grosir Tanah Abang Jakarta Pusat)
}

\author{
Endro Andayani \\ Institut Ilmu Sosial dan Manajemen Stiami \\ endro@stiami.ac.id
}

\begin{tabular}{|c|c|c|}
\hline ARTIKE & L INFO & ABSTRACT \\
\hline Keywords: & $\begin{array}{l}\text { Tax Requlation } \\
\text { PP 46, 2013, } \\
\text { SMEs, Tax } \\
\text { Knowledge, } \\
\text { Administration, } \\
\text { Benefits, } \\
\text { Sanctions and } \\
\text { Socialization, } \\
\text { Taxpayer } \\
\text { Compliance. }\end{array}$ & $\begin{array}{l}\text { This research is an annual background by implementation of PP } 46,2013 \text { to } \\
\text { facilitate SMEs Taxpayer with omzet of less than 4,8 M. This research, } \\
\text { especialy analyzed the factors's that effects the complienceness of the } \\
\text { implementation of PP 46,2013 on SMEs Taxpayer with variables such as } \\
\text { perception of justice, tax knowledge of PP 46, 2013, Tax Administration, } \\
\text { Benefits, Sanctions and Goverment socialization, partially or simultaneously. } \\
\text { This research using quantitative appoach, The data used are primary data, } \\
\text { collected using quetionnaires fill by respondents, chosen using non } \\
\text { probabilty sampling, and sampling technique by purposive sampling.Data } \\
\text { analyzed using multiple linear regression. The population of this study are } \\
\text { small business and Enterpreneurships in wholesale center Tanah Abang with } \\
\text { annual gross income less than 4,8 M, criteria by gender, education } \\
\text { backgrounds, business longevity, incorporated or have a NPWP } \\
\text { (Identification Legal Entity Tax Payer Goverment) and monthly average } \\
\text { sales. The results of this study indicates that perception of justice of PP } 46 \text {, } \\
\text { 2013, Knowledge of PP 46, 2013, Administration, Benefit, Sanctions and } \\
\text { Socialization, takes effect on SMEs tax payer compliance in the wholesale } \\
\text { center Tanah Abang. The samples used in this study were } 86 \text { respondents } \\
\text { The results of this indicates that perception of justice of PP } 46,2013 \text {, } \\
\text { Knowledge of PP 46, 2013, Administration, Benefit, Sanctions and } \\
\text { Socialization, takes effect on SMEs tax payer compliance in the wholesale } \\
\text { center Tanah Abang either partially or simultaneously. }\end{array}$ \\
\hline
\end{tabular}

\section{PENDAHULUAN}

Pajak merupakan aspek penting bagi pendapatan Negara Indonesia. Sumber pendapatan negara dari pajak telah menjadi unsur utama dalam menunjang kegiatan perekonomian, menggerakkan roda pemerintahan dan penyediaan fasilitas umum seperti jalan-jalan, sekolah, jembatan, rumah sakit/puskesmas, kantor polisi. Pajak Merupakan Iuran kepada negara yang dipaksakan dengan tanpa mendapat jasa timbal balik yang langsung dan merupakan tolak ukur dari keberhasilan perekonomian suatu negara, sehingga kesadaran masyarakat dalam membayar pajak sangat penting untuk penerimaan negara.

Target penerimaan pajak yang terus meningkat dari tahun ketahun menuntut Direktorat Jenderal Pajak (DJP) mengoptimalkan penerimaan pajak yang ditargetkan sesuai APBN-P 2015 sebesar Rp. 1.294 triliun. Berdasarkan sumber keuangan negara atau APBN-P menunjukkan bahwa prosentase realisasi penerimaan pajak dari target yang ditetapkan pada periode tahun 2011 sampai dengan 2014 cenderung mengalami penurunan setiap tahun sebesar kurang lebih 2-3\% per tahun. Data berikut menunjukan prosentase antara target dan realisasi penerimaan pajak : 
Tabel 1. Target dan Realisasi Pajak dalam ABPN-P Tahun 2009 - 2014

(Dalam Triliunan Rupiah)

\begin{tabular}{lccc}
\hline & Target & Realisasi & Persentase \\
\hline $\mathbf{2 0 0 9}$ & 652 & 620 & $95.1 \%$ \\
$\mathbf{2 0 1 0}$ & 743 & 723 & $97.3 \%$ \\
$\mathbf{2 0 1 1}$ & 879 & 874 & $99.4 \%$ \\
$\mathbf{2 0 1 2}$ & 1.016 & 981 & $96.4 \%$ \\
$\mathbf{2 0 1 3}$ & 1.148 & 1.077 & $93.8 \%$ \\
$\mathbf{2 0 1 4}$ & 1.246 & 1.143 & $91.7 \%$ \\
\hline
\end{tabular}

(Sumber: www.pajak.go.id)

Dalam rangka mencapai target penerimaan pajak, Direktorat Jenderal Pajak (DJP) senantiasa melakukan pengembangan kapasitas organisasi melalui penguatan sumber daya manusia, penguatan teknologi informasi, penguatan organisasi, penguatan anggaran dan penguatan proses bisnis, dan pemanfaatan data perpajakan dari pihak ketiga, antara lain data dari Pusat Pelaporan dan Analisis Transaksi Keuangan (PPATK), Otoritas Jasa Keuangan (OJK), Bank Indonesia (BI), Badan Pertanahan Nasional (BPN). Melalui Media Briefing strategi pajak 2014 yang diterbitkan melalui website resmi Direktorat Jenderal Pajak (DJP), salah satu bentuk program kerja strategis adalah memperluas basis pajak, termasuk kepada sektor-sektor yang selama ini tidak terlalu banyak digali potensinya. Menurut Direktorat Jenderal Pajak, sektor yang akan digali potensinya karena belum tersentuh secara maksimal diantaranya sektor perdagangan (Usaha Mikro Kecil dan Menengah) yang memiliki tempat usaha di pusat-pusat perbelanjaan dan sektor properti (www.kemenkeu.go.id).

Berdasarkan data Badan Pusat Statistik (BPS), Perkembangan UMKM di Indonesia dalam periode tahun 2009 sampai dengan 2012 mengalami peningkatan, terlihat dalam tabel 2 : Pada periode tahun 2012, jumlah UMKM mencapai 56,5 juta unit, menyerap tenaga kerja 107,6 juta orang, memberikan kontribusi pada Produk Domestik Bruto (PDB) nasional dengan pertumbuhan sumbangan PDB sebesar 9,9 \%, dan jumlah nilai ekspor juga mengalami perkembangan sebesar Rp 208 triliun.

Tabel 2. Perkembangan UMKM Periode 2009- 2012

\begin{tabular}{|c|c|c|c|c|c|c|}
\hline \multirow{2}{*}{ No. } & \multirow{2}{*}{ Indikator } & \multirow{2}{*}{ Satuan } & \multicolumn{4}{|c|}{ Tahun } \\
\hline & & & 2009 & 2010 & 2011 & 2012 \\
\hline 1. & Jumlah UMKM & Unit & 52.764 .603 & 53.823 .732 & 55.206 .444 & 56.534 .592 \\
\hline 2. & $\begin{array}{l}\text { Pertumbuhan Jumlah } \\
\text { UMKM }\end{array}$ & Persen & 2,64 & 2,01 & 2,57 & 2,41 \\
\hline 3. & $\begin{array}{l}\text { Jumlah Tenaga Kerja } \\
\text { UMKM }\end{array}$ & Orang & 96.211 .332 & 99.401 .775 & 101.722 .458 & 107.657 .509 \\
\hline 4. & $\begin{array}{l}\text { Pertumbuhan Jumlah } \\
\text { Tenaga Kerja }\end{array}$ & Persen & 2,33 & 3,32 & 2,33 & 5,83 \\
\hline 5. & $\begin{array}{l}\text { Sumbangan } \\
\text { UMKM }\end{array}$ & Miliar Rp & 1.212 .599 & 1.282 .571 & 1.369 .326 & 1.504 .928 \\
\hline 6. & $\begin{array}{l}\text { Pertumbuhan } \\
\text { Sumbangan PDB }\end{array}$ & Persen & 4,02 & 5,77 & 6,76 & 9,90 \\
\hline 7. & Nilai Ekspor UMKM & Miliar Rp & 162.254 & 175.894 & 187.441 & 208.067 \\
\hline 8. & $\begin{array}{l}\text { Pertumbuhan Nilai } \\
\text { Ekspor }\end{array}$ & Persen & -8.85 & 8,41 & 6,56 & 11,00 \\
\hline
\end{tabular}

(Sumber : www.bps.go.id)

Periode saat ini jumlah UMKM di Indonesia sudah mencapai 57,9 juta unit, analisis Badan Pusat Statistik (BPS) menyumbang sekitar $60 \%$ dari total Gross Domestic Product (GDP) dan menampung $97 \%$ dari total tenaga kerja. Kontribusi usaha mikro kecil dan menengah (UMKM) terhadap perekonomian Indonesia belakangan ini menjadi menarik dan ramai diperbincangkan mengingat jumlah lapangan kerja yang besar dan peranan yang besar terhadap produk domestik bruto. Usaha Mikro Kecil dan Menengah (UMKM) berperan dominan terhadap perekonomian nasional, apabila dikaitkan dengan pemenuhan kewajiban perpajakan di Indonesia, terlihat bahwa kepatuhan pajak Usaha Mikro Kecil dan Menengah (UMKM) masih belum memadai, jumlah Usaha Mikro Kecil 
dan Menengah (UMKM) di atas 50 juta unit, jumlah pembayar pajak "orang pribadi" yang memiliki Nomor Pokok Wajib Pajak (NPWP) masih sekitar 20 juta.

Menurut Inasius (2012) ada beberapa alasan mengapa pembayar pajak Usaha Mikro Kecil dan Menengah (UMKM) belum maksimal berkontribusi dalam penerimaan pajak. Pertama, usaha dengan karakteristik tersebut mengalami kendala utama dalam bidang administrasi. Secara umum perkembangan Usaha Mikro Kecil dan Menengah (UMKM) dimulai dari usaha perorangan, yang jika berkembang, berbentuk badan dengan skala kecil menengah. Beban administrasi yang kompleks akan meningkatkan biaya kepatuhan pajak yang dapat menurunkan daya saing Usaha Mikro Kecil dan Menengah (UMKM), yang berdampak terhadap tingkat kepatuhan pajak yang rendah.

Kedua, tarif pajak yang tidak kompetitif bagi pembayar pajak Usaha Mikro Kecil dan Menengah (UMKM) untuk berkompetisi dengan non-Usaha Mikro Kecil dan Menengah (UMKM). Sebagai contoh, bagi para pelaku Usaha Mikro Kecil dan Menengah (UMKM) pajak merupakan komponen biaya dalam penghitungan sederhana. Jika tingkat keuntungan sebelum pajak 10\% dengan Pajak Penghasilan (PPh) 1\% dan PPN 3\%, akan dihasilkan keuntungan 6\%. Dengan penghitungan sederhana ini, para pengusaha Usaha Mikro Kecil dan Menengah (UMKM) akan mudah melaksanakan pemenuhan kewajiban pajaknya, tentu saja dengan memprediksi keuntungan yang dapat direalisasikan.

Ketiga, pengaruh etika dan lingkungan terhadap tingkat kepatuhan pembayar pajak Usaha Mikro Kecil dan Menengah (UMKM). Pengaruh lingkungan seperti adanya ketidakjujuran Wajib Pajak Usaha Mikro Kecil dan Menengah (UMKM) lainnya dan pengaruh keluarga .

Keempat, kecil kemungkinan untuk terdeteksi aparat pajak karena jumlah pemeriksa pajak yang masih terbatas. Pemeriksaan pajak menjadi menjadi hal yang penting karena adanya kemungkinan diperiksa oleh otoritas pajak atau terdeteksi atas kewajiban pajak dalam memungut, menyetor dan melaporkan, berdampak terhadap tingkat kepatuhan wajib pajak.

Berdasarkan keempat alasan, Pajak Penghasilan (PPh) perpajakan atas Usaha Mikro Kecil dan Menengah (UMKM) terdiri atas dua jenis pajak utama yang memiliki peran signifikan, yaitu Pajak Penghasilan (PPh) dan Pajak Pertambahan Nilai (PPN), dengan Pajak Penghasilan (PPh) sebagai pajak dominan. Berdasarkan Peraturan Pemerintah (PP) Nomor 46, wajib pajak dengan peredaran usaha di bawah Rp 4,8 miliar dikenakan Pajak Penghasilan (PPh) 1\% dari total peredaran usaha dan bersifat final. Pelaku Usaha Mikro Kecil dan Menengah (UMKM) tidak harus menghitung secara tepat berapa keuntungan yang dihasilkan karena pajak tersebut bersifat final sehingga tidak dipengaruhi oleh jumlah keuntungan. Ini berarti pembayar pajak di sektor ini dipermudah, baik dari segi administrasi maupun tarif yang kompetitif (Inasyius, 2012). Peraturan yang mengatur tentang hal ini adalah Peraturan Menteri Keuangan (PMK) Nomor 197.

Terkait kebijakan dalam Peraturan Pemerintah Nomor 46/2013 dan PMK No. 197/2013, tidak saja membawa angin segar bagi pelaku Usaha Mikro Kecil dan Menengah (UMKM) dengan tarif yang kompetitif, tetapi juga kesederhanaan dalam pemenuhan kewajiban pelaporan pajak tahunan. Karena itu, kombinasi tentang Pajak Penghasilan (PPh) 1\% dan peningkatan batasan untuk jadi Penghasilan Kena Pajak (PKP) adalah solusi yang selaras menunjang tingkat kepatuhan wajib pajak Usaha Mikro Kecil dan Menengah (UMKM).

Berdasarkan survei dari Direktorat Jendral Pajak (DJP) dalam Tiong (2014), tingkat kepatuhan masyarakat dalam melaksanakan kewajiban perpajakan masih rendah. Tercatat untuk wajib pajak orang pribadi, dari potensi sekitar 60 juta orang baru sekitar 25 juta yang telah membayar pajak. Wajib Pajak Badan sekitar 520 WP yang membayar pajak dari sekitar 5 juta badan usaha yang memiliki laba. Pelaku UKM masih jauh dari harapan, berdasarkan Sensus Pajak Nasional (SPN). Direktorat Jendral Pajak (DJP) berkeyakinan bahwa pelaku UKM wajib dikenai pajak penghasilan. Birokrasi dan administrasi perpajakan juga perlu diperbaiki, karena banyak perilaku ketidakpatuhan dalam melaksanakan kewajiban perpajakan akibat mengalami kesulitan dalam memahami administrasi perpajakan.

Kepatuhan wajib pajak dalam memenuhi kewajiban perpajakannya diletakkan sebagai isu yang utama, mengingat pada saat yang bersamaan akan muncul Tax Evasion atau penggelapan pajak yang berpengaruh terhadap besarnya penerimaan negara. Persentase tingkat kepatuhan wajib pajak pada tahun 2012 masih tergolong sangat rendah, tidak jauh berbeda dari tahun-tahun sebelumnya (http://www.pajak.go.id). Menurut Menteri Kuangan Republik Indonesia Agus Martowardojo mengatakan bahwa orang pribadi yang seharusnya membayar pajak atau yang mempunyai penghasilan 
diatas Penghasilan Tidak Kena Pajak (PTKP) sebanyak 60 juta orang, tetapi jumlah yang mendaftarkan diri sebagai wajib pajak hanya 20 juta dan yang membayar pajaknya atau melaporkan Surat Pemberitahuan (SPT) Pajak Penghasilannya hanya 8,8 juta orang dengan rasio SPT sekitar $14,7 \%$. Sementara badan usaha yang terdaftar sebanyak 5 juta, yang mau mendaftarkan dirinya sebagai wajib pajak hanya 1,9 juta dan yang membayar pajak atau melapor Surat Pemberitahuan (SPT) Pajak Penghasilan hanya 520 ribu badan usaha dengan rasio SPT sekitar 10,4\%.(http://www.pajak.go.id).

Terdapat beberapa faktor yang mempengaruhi perilaku kepatuhan wajib pajak. Menurut Jackson \& Milliron yang dikutip oleh Harri (2008), keadilan pajak (Tax Fairness) merupakan kunci variabel non ekonomi yang mempengaruhi perilaku kepatuhan pajak. Pendapat terssebut didukung oleh pendapat Vogel, Spicer dan Becker yang dikutip oleh Harri (2008) bahwa pembayar pajak cenderung untuk menghindari pajak jika mereka menganggap bahwa sistem pajak tidak adil. Lalu bagaimanakah konsep keadilan pajak tersebut didefinisikan? Pada kenyataannya, untuk mendefinisikan konsep keadilan pajak sendiri masih menjadi masalah bagi para peneliti. Menurut Christensen et al (1994) yang dikutip dalam Rivai (2009:855) hal ini dikarenakan keadilan pajak merupakan konsep yang multidimensional yaitu konsep yang dapat diartikan dari berbagai sudut pandang berdasarkan pendekatan yang dilakukan oleh peneliti. Disamping itu, konsep keadilan pajak dapat didefinisikan baik pada tingkatan individu maupun sosial, keadilan pajak dan kompleksitas pajak dapat dipersepsikan sebagai pembenaran sebagai penyebab ketidakpatuhan.

Faktor pertimbangan atas terbitnya Peraturan Pemerintah No 46 Tahun 2013 ini adalah adanya persepsi masyarakat yang menganggap tidak terdapat aspek keadilan. Pengenaan PPh yang bersifat final bermakna bahwa pelunasan PPh 1 persen dihitung dari peredaran bruto setiap bulan, kewajiban pajak atas penghasilan bersifat final. Ditinjau dari konsep keadilan dalam pemajakan (equity principle), pengenaan PPh Final tidak sesuai dengan keadilan karena tidak mencerminkan kemampuan membayar (ability to pay). Pemajakan yang adil adalah bahwa semakin besar penghasilan maka semakin besar pula pajak yang harus dibayar (the more you earn, the more you pay tax).

Melalui penelitian, Gerbing yang dikutip dalam Giligant dan Richardson (2005) mendefinisikan konsep dimensi keadilan pajak ke dalam lima variabel yaitu general fairness, exchange with the government, self interest, self provisions, dan tax rate structure. Kemudian dimensi keadilan pajak yang telah dikembangkan oleh Gerbing tersebut dijadikan acuan oleh beberapa peneliti dalam melakukan penelitian mengenai pengaruh dimensi keadilan pajak terhadap perilaku kepatuhan Wajib Pajak. Pada awalnya penelitian tersebut banyak dilakukan di negara barat, jarang peneliti menggunakan negara Asia sebagai objek penelitian. Giligant dan Richardson (2005) menyatakan bahwa perlu untuk melakukan penelitian-penelitian di negara lain untuk memperkaya pengetahuan tentang variabel keadilan pajak yang mempengaruhi perilaku kepatuhan.

Faktor lain adalah pemahaman pelaku UMKM atas PP No. 46 Tahun 2013, sosialiasi DJP atas PP No. 46 Tahun 2013, sanksi yang dikenakan atas pelanggaran terhadap PP No. 46 Tahun 2013 serta pemahaman tentang manfaat dari PP No. 46 Tahun 2013 juga menjadi faktor penentu atas keberhasilan pelaksanaan PP No. 46 Tahun 2013. Menurut Carolina (2009:7), pengetahuan pajak adalah informasi pajak yang dapat digunakan wajib pajak sebagai dasar untuk bertindak, mengambil keputusan, dan untuk menempuh arah atau strategi tertentu sehubungan dengan pelaksanaan hak dan kewajibannya dibidang perpajakan.

Menurut Rahayu S (2010:141), pentingnya aspek pengetahuan perpajakan bagi wajib pajak sangat mempengaruhi sikap pajak terhadap system perpajakan yang adil. Dengan kualitas pengetahuan yang semakin baik akan memberikan sikap memenuhi kewajiban dengan benar melalui adanya system perpajakan sesuatu Negara yang dianggap adil. Kesadaran wajib pajak akan meningkat bilamana dalam masyarakat muncul persepsi terhadap pajak. Dengan meningkatnya pengetahuan perpajakan masyarakat melalui pendidikan perpajakan baik formal maupun non formal akan berdampak positif terhadap pemahaman dan kesadaran wajib pajak dalam membayar pajak. Dengan penyuluhan perpajakan secara intensif dan kontinyu akan meningkatkan pemahaman wajib pajak tentang kewajiban membayar pajak sebagai wujud gotong royong nasional dalam menghimpun dana untuk kepentingan pembiayaan pemerintahan dan pembangunan nasional.

Faktor lain, bagaimana PP No. 46 Tahun 2013 ini dapat mempermudah kewajiban UMKM dalam hal administrasi perpajakannya juga menjadi faktor penentu atas keberhasilan pelaksanaan PP No. 46 Tahun 2013 ini. Administrasi merupakan suatu proses dinamis dan berkelanjutan yang 
digerakkan dalam rangka mencapai tujuan dengan cara memanfaatkan orang dan material melalui koordinasi dan kerja sama. Definisi tersebut di atas menunjukkan beberapa batasan istilah administrasi bukan hanya sebatas kegiatan ketatausahaan yang berkaitan dengan pekerjaan mengatur berkas, membuat laporan administrative, dan sebagainya. Modernisasi administrasi merupakan perubahan yang diberlakukan oleh DJP sejak tahun 2002. Modernisasi ini juga merupakan bagian dari blue print yang sudah ditetapkan oleh DJP (Indonesia Tax Review, Vol IV, Edisi 23.2007:2). Menurut Pandiangan (2007:8), administrasi perpajakan berperan penting dalam sistem perpajakan disuatu negara. Suatu negara dapat dengan sukses mencapai sasaran yang diharapkan dalam menghasilkan penerimaan pajak yang optimal karena administrasi perpajakannya mampu dengan efektif melaksanakan sistem perpajakan di suatu negara yang dipilih.

Winerungan (2013) mengatakan sosialisasi perpajakan juga dapat berpengaruh untuk menambah jumlah wajib pajak dan dapat menimbulkan kepatuhan dari wajib pajak sehingga secara otomatis tingkat kepatuhan wajib pajak dan penerimaan pajak negara akan semakin meningkat. Syahril (2013) mengatakan apabila pelayanan yang diberikan oleh fiskus baik, maka tingkat kepatuhan wajib pajak dalam melaksanakan kewajibannya juga meningkat.

Perbedaan dengan penelitian sebelumnya terletak pada penambahan atau penggabungan beberapa variabel dan lokasi atau obyek penelitian. Penelitian dilakukan di salah satu pusat perekonomian yang banyak menampung UMKM adalah Pasar Tanah Abang. Sampai saat ini Pasar Tanah Abang menjadi pusat bisnis dan grosir terbesar se-Asia Tenggara (www.thamrincity3a.com). Selain itu perbedaan lainnya adalah jumlah populasi dan sampel yang digunakan. Dalam penelitian ini populasinya berkisar 600 UMKM yang hanya beroperasi pada gedung Pusat Grosir Metro Tanah Abang (PGMTA).

Berdasarkan faktor-faktor yang mempengaruhi Kepatuhan Wajib Pajak, maka penulis menggambarkan hubungan tersebut dalam skema kerangka pemikiran sebagai berikut :

\section{Gambar 1. Kerangka Pemikiran}

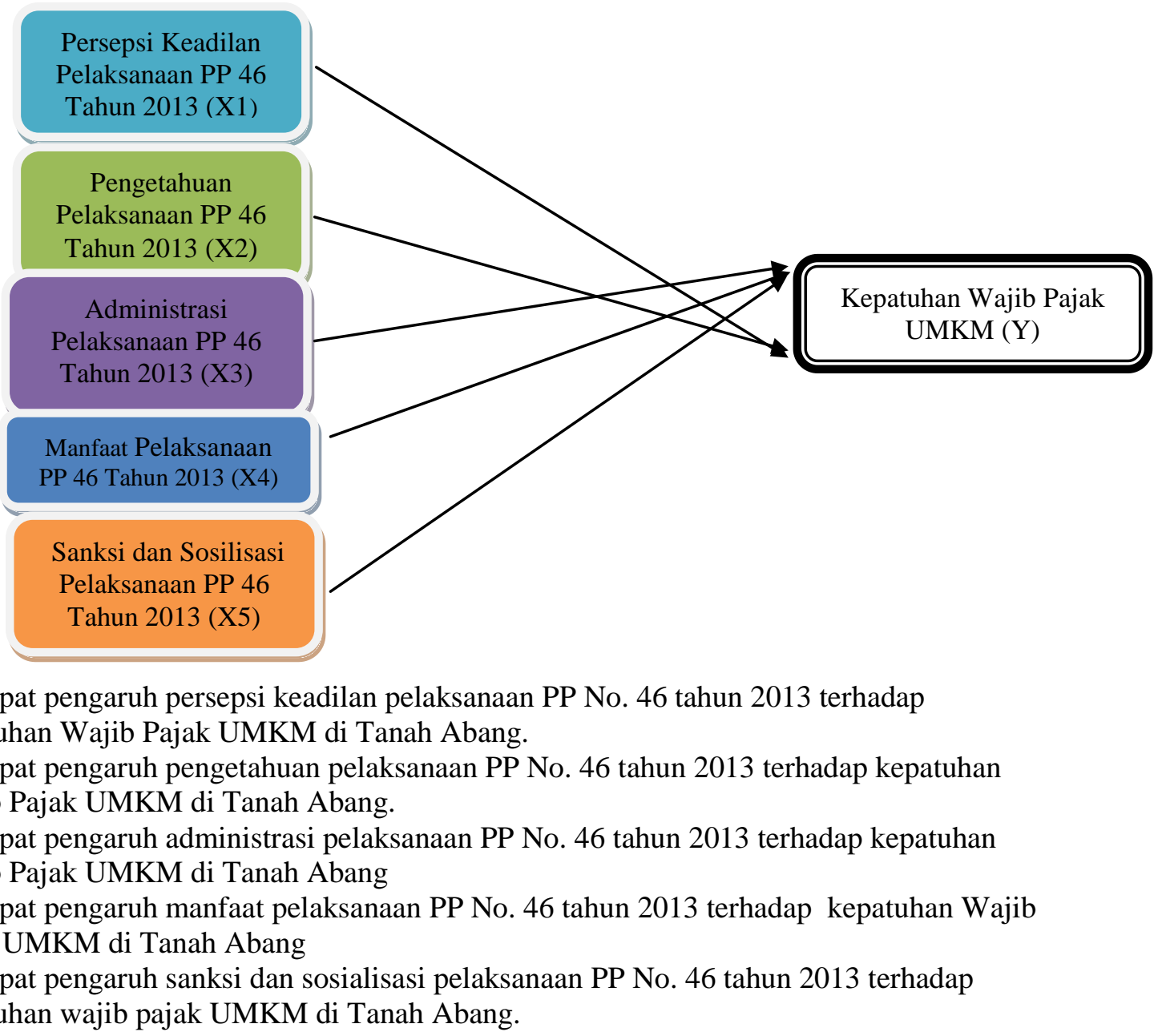




\section{DESAIN DAN METODE PENELITIAN Jenis Penelitian}

Pendekatan kuantitatif yang dilakukan dalam penelitian ini menggunakan metode penelitian deskriptif dan eksplanatif (Nazir 2005:54).Penelitian deskriptif merupakan suatu metode dalam meneliti status sekelompok manusia, suatu obyek, suatu set kondisi, suatu sistem pemikiran ataupun peristiwa ataupun peristiwa pada masa sekarang. Tujuan dari penelitian deskriptif membuat deskriptif, tabelan, atau lukisan secara sistematis, faktual dan aktual mengenai fakta-fakta, sifat-sifat serta hubungan antara fenomena yang diselidiki.Penelitian eksplanatif diartikan menjelaskan hubungan kausal antara variabel-variabel melalui pengujian hipotesa dengan pendekatan kuantitatif, yang bertujuan untuk mengetahui pengaruh variabel independent yaitu Persepsi keadilan (X1), Pengetahuan(X2), Administrasi (X3), Manfaat (X4), Sanksi dan Sosialisasi (X5), terhadap variabel independent yaitu kepatuhan Wajib Pajak (Y)

\section{Definisi dan Operasionalisasi Variabel}

Tabel 3. Operasionalisasi Variabel

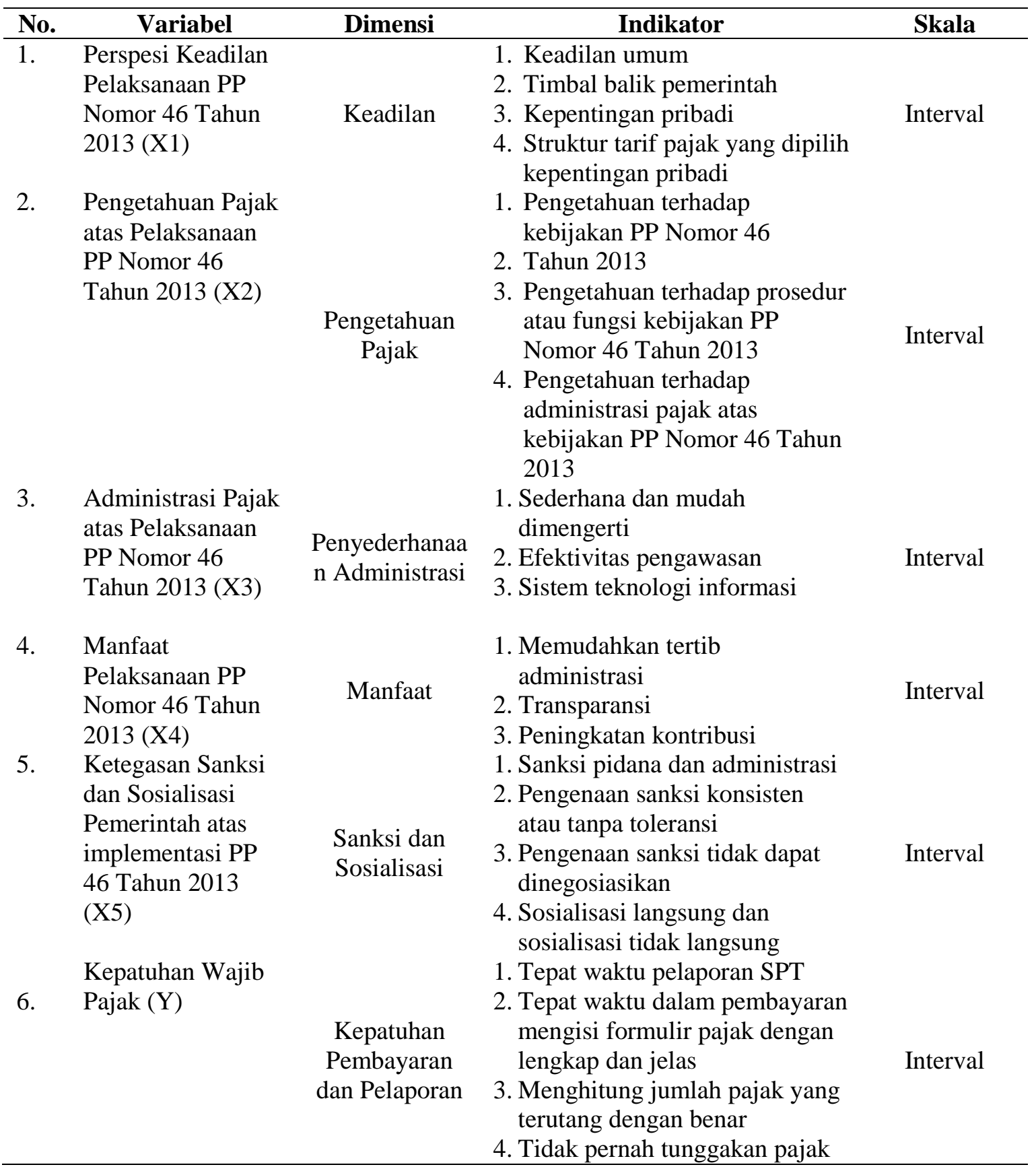

Sumber: dikutip berbagai sumber 


\section{Pengukuran Variabel}

Menurut Sugiyono (2009:86), setiap pernyataan pada skala Likert diberi skor. Pernyataan yang bersifat memberi dukungan disebut Kuesioner Positif responden harus menggambarkan, mendukung pernyataan (item positif) atau tidak sedangkan yang bersifat tidak mendukung disebut Kuesioner Negatif.

\section{Populasi dan Sampel}

Menurut Sugiyono (2010:115), populasi adalah wilayah generalisasi yang terdiri atas obyek atau subyek yang mempunyai kualitas dan karakteristik tertentu yang ditetapkan oleh peneliti untuk dipelajari dan kemudian ditarik kesimpulannya. Populasi bukan hanya orang, tetapi juga obyek dan benda-benda alam yang lain. Populasi juga bukan sekedar jumlah yang ada pada obyek atau subyek yang dipelajari, tetapi meliputi seluruh karakteristik atau sifat yang dimiliki oleh subyek atau obyek itu. Populasi yang digunakan dalam penelitian ini adalah Usaha Mikro Kecil dan Menengah Pusat Grosir Tanah Abang.

Metode pengambilan responden yang digunakan dalam penelitian ini adalah non probability sampling, dan teknik pengambilan sampel dengan purposive sampling adalah sesuai dengan rumus sebagai berikut :

$$
\mathbf{n}=\frac{\mathbf{N}}{-\left(\mathrm{N} \cdot \mathrm{d}^{2}\right)+1}
$$

\section{Teknik Pengumpulan Data}

Menurut Sugiyono (2010:193), pengumpulan data dapat dilakukan dalam berbagai sumber dan cara . Dilihat dari sumber data, data yang digunakan dalam penelitian ini adalah data primer . Data primer adalah data yang langsung memberikan data kepada pengumpul data (Sugiyono, 2010:193) . Sedangkan jika dilihat dari segi cara atau teknik pengumpulan data dalam penelitian ini dengan cara : Teknik Observasi dan Teknik Kuesioner.

\section{Metode Analisis Data}

\section{Statistik Deskriptif}

Deskripsi data ini yang disajikan dengan bentuk skor maksimum, skor minimum, mean serta standar deviasinya. Deskripsi tersebut berguna untuk mengukur tingkat minimum serta rata-rata (mean) data menurut variabel-variabel yang diolah.

\section{Uji Kualitas Data}

\section{Uji Validitas}

Uji validitas digunakan untuk mengukur apakah terdapat pertanyaan-pertanyaan pada kuesioner yang harus dibuang atau diganti karena dianggap tidak relevan. Menurut Husein Umar (2013:166) dapat digunakan rumus korelasi product moment sebagai berikut :

$$
r=\frac{n \sum X_{i} Y_{i}-\left(\sum X_{i}\right)\left(\sum Y_{i}\right)}{\left.\sqrt{\left[n \sum X_{i}^{2}-\left(\sum X_{i}\right)^{2}\right.}\right] \sqrt{\left[n \sum Y_{i}^{2}-\left(\sum Y_{i}\right)^{2}\right]}}
$$

\section{Uji Reabilitas}

Uji reliabilitas digunakan untuk mengukur derajat ketepatan, ketelitian atau keakuratan dari instrumen pengukuran. Untuk pengujian reliabilitas ini penulis menggunakan metode Alpha (AlphaCronbach method). Suatu data dikatakan akurat jika nilai koefisien Alpha-Cronbach (dari hasil SPSS) adalah lebih besar dari 0,6 (Santoso, 2013:54). 


\section{Uji Asumsi Klasik}

Uji Asumsi klasik adalah pengujian terhadap ada tidaknya pelanggaran terhadap asumsiasumsi klasik yang merupakan dasar dalam model regresi linier berganda. Hal ini dilakukan sebelum dilakukan pengujian terhadap hipotesis.

a. Uji Normalitas Regresi

Jika sig $<0,05$, maka Ho ditolak, Jika sig $>0,05$, maka Ho diterima

b. Uji Multikolinieritas

Pedoman suatu model regresi yang bebas multikolinieritas adalah mempunyai nilai VIF disekitar angka 1 sampai 10, dan mempunyai angka tolerance mendekati 1. dengan menggunakan SPSS versi 23

c. Uji Heteroskedastisitas

Uji ini dilakukan dengan cara grafik dimana menunjukan model regresi bebas dari Heteroskedastisitas atau dengan kata lain disebut dengan homoskedastisitas.

\section{Uji Regresi Linier Berganda}

Uji regresi linier berganda bertujuan untuk melihat pengaruh tingkat Persepsi Keadilan, Pengetahuan pajak, Administrasi pajak, Manfaat, Sanksi dan Sosialisasi Pelaksanaan PP Nomor 46 Tahun 2013 terhadap Kepatuhan Wajib Pajak. Hubungan linier dapat dinyatakan sebagai berikut :

$$
\mathrm{Y}=\mathrm{a}+\mathrm{b}_{1} \mathrm{x}_{1}+\mathrm{b}_{2} \mathrm{x}_{2}+\mathrm{b}_{3} \mathrm{x}_{3}+\mathrm{b}_{4} \mathrm{X}_{4}+\mathrm{b}_{5} \mathrm{x}_{5}+\mathrm{e}
$$

\section{Uji Koefisien Determinasi}

Uji koefisien Determinasi $\left(\mathrm{R}^{2}\right)$, melihat berapa proporsi variasi dari variabel bebas secara bersama-sama dalam mempengaruhi variabel tidak bebas, dengan formula (Sugiyono 2010:231) sebagai berikut: $\mathrm{KD}=\mathrm{r}^{2} \times 100 \%$

\section{Uji Hipotesis}

a. Uji T Statistik

Uji-t statistik, untuk menguji pengaruh secara parsial antara variabel bebas terhadap variabel tidak bebas dengan asumsi bahwa variabel lain dianggap konstan, dengan tingkat keyakinan $95 \%(\alpha=0,05)$, Urutan uji $\mathrm{t}$ : Hipotesa Null atau Hipotesa Alternatif, Menghitung $\mathrm{F}$ Hitung dan kriteria pengujian.

b. Uji F Statistik

Uji $\mathrm{F}$, dengan maksud menguji apakah secara simultan variabel bebas berpengaruh terhadap variabel tidak bebas, dengan tingkat keyakinan 95\% $(\alpha=0,05)$, urutan uji F meliputi: Hipotesa Null atau Hipotesa Alternatif, Menghitung F Hitung dan kriteria pengujian.

\section{HASIL DAN PEMBAHASAN}

\section{Karakteristik Umum Responden Penelitian}

Hasil penelitian berdasarkan jenis kelamin dari 86 responden menunjukkan bahwa rata -rata pengusaha / penanggung jawab UMKM Tanah abang memiliki prosentase terbesar pada jenis kelaman laki-laki sebesar 54,7 \%, tingkat pendidikan maksimum SMA sebesar 66,3\%, lama menjalankan usaha 5-10 tahun sebesar 41,9 \%, memiliki NPWP dan berbadan hukum 94,2 \%, dan rata -rata penjualan Rp 500.000.000 s/d Rp 700.000.000 sebesar 44,2 \%. 
Statistik Deskriptif

Tabel 4. Statistik Deskriptif

(Descriptive Statistics)

\begin{tabular}{|c|c|c|c|c|c|}
\hline & $\mathrm{N}$ & Minimum & Maximum & Mean & Std. Deviation \\
\hline Persepsi Keadilan & 86 & 17.00 & 26.00 & 21.0116 & 1.94328 \\
\hline Pengetahuan Pajak & 86 & 21.00 & 32.00 & 27.3256 & 2.28263 \\
\hline Administrasi Pajak & 86 & 18.00 & 28.00 & 23.9302 & 1.88362 \\
\hline Manfaat PP No 46 & 86 & 17.00 & 26.00 & 20.9186 & 2.02464 \\
\hline Sosialisasi dan Sanksi & 86 & 21.00 & 30.00 & 24.2326 & 1.87035 \\
\hline Kepatuhan Wajib Pajak & 86 & 17.00 & 24.00 & 20.8488 & 1.85674 \\
\hline Valid N (listwise) & 86 & & & & \\
\hline
\end{tabular}

Sumber : Pengolahan Data Dengan Program SPSS 23.00

Berdasarkan tabel di atas, diketahui bahwa variabel persepsi keadilan memiliki nilai minimum sebesar 17.00 dan maksimum sebesar 26.00, dengan menghasilkan nilai rata-rata 21.01 dan standar deviasi 1.94. Dilihat dari standar deviasinya (simpanan baku) yang kuat dan kecenderungan mendekati nilai mean, sehingga menunjukan deviasi positif sehingga seluruh variabel independent memeliki persepsi yg positif terhadap keadilan, sistem administrasi pajak, manfaat, sosialisasi dan sanksi , dan mempunyai pengetahuan yang cukup.

\section{Uji Validitas dan Reabilitas}

Berdasarkan uji Validitas menunjukan bahwa seluruh butir pertanyaan pada variabel Independent adalah valid dan Variabel Dependent (kepatuhan wajib pajak adalah valid, karena nilai rhitung setiap pertanyaan lebih besar dibandingkan t-tabel $(0,212)$.

Berdasarkan uji Reabilitas, atas Variabel keadilan yang di hasilkan, diperoleh nilai Alpha Cronbach's dari 6 pertanyaan tersebut adalah 0,840 >0.60, Variabel pengetahuan pajak sebesar 0,77 $>0,60$, Variabel Administrasi 0,87>0,60, Manfaat 0,727 >0,60 dan sosialisasi dan sanksi 0,920>0,60, dengan demikian item-item pertanyaan tersebut realiabel atau dapat diandalkan.

\section{Uji Asumsi Klasik}

Tabel 5. Uji Asumsi Klasik Normalitas Regresi

One-Sample Kolmogorov-Smirnov Test

\begin{tabular}{|ll|r|}
\hline & & $\begin{array}{c}\text { Unstandardized } \\
\text { Residual }\end{array}$ \\
\hline $\mathrm{N}$ & & 86 \\
Normal Parameters & Mean & .0000000 \\
& Std. Deviation & 1.12008031 \\
Most Extreme Differences & Absolute & .076 \\
& Positive & .076 \\
& Negative & -.054 \\
Kolmogorov-Smirnov Z & & .706 \\
Asymp. Sig. (2-tailed) & & .701 \\
\hline
\end{tabular}

a. Test distribution is Normal.

b. Calculated from data.

Berdasarkan hasil pengujian diatas dapat dilihat bahwa variabel independen dan dependen yaitu persepsi keadilan (X1), pengetahuan pajak (X2), administrasi pajak (X3), manfaat PP No. 46 tahun 2013 (X4), sosialisasi dan sanksi (X5) serta kepatuhan wajib pajak (Y) memiliki signifikansi $0.701>0.05$. Hal ini menggambarkan bahwa keluruhan variabel independen dan dependen tersebut terdisitribusi normal. 
Tabel 6. Uji Asumsi Klasik Multikolinieritas

\begin{tabular}{llcc}
\multicolumn{4}{c}{ Coefficients $^{\mathbf{a}}$} \\
\hline \multirow{2}{*}{ Model } & \multicolumn{2}{c}{ Collinearity } & Statistics \\
& & Tolerance & VIF \\
\hline $1 \quad$ Persepsi Keadilan & .902 & 1.108 \\
& Pengetahuan Pajak & .368 & 2.718 \\
Administrasi Pajak & .369 & 2.707 \\
Manfaat PP No 46 & .760 & 1.316 \\
Sosialisasi dan Sanksi & .689 & 1.451 \\
\hline
\end{tabular}

a. Dependent Variable: Kepatuhan Wajib Pajak

Sumber : Pengolahan Data Dengan Program SPSS 23.00

Pada tabel di atas menunjukkan bahwa semua angka VIF berada di angka antara 1 dan 10 serta angka tolerance di bawah atau mendekati angka 1. Hal ini dapat disimpulkan bahwa dalam kasus ini semua data yang digunakan bebas dari multikolinieritas: Uji Asumsi Klasik Heteroskedastisitas

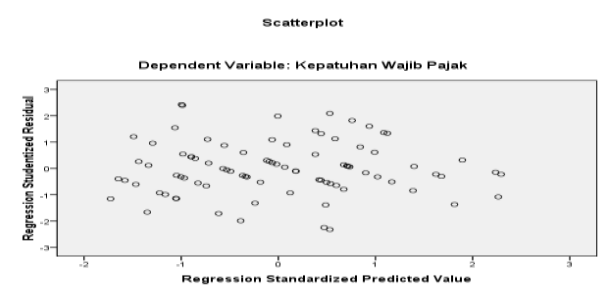

Sumber : Pengolahan Data Dengan Program SPSS 23.00

Uji Heteroskedastisitas dapat dilakukan dengan cara grafik. Dari grafik Scatterplot yang disajikan yang terdapat pada gambar 4.2 di bawah, terlihat titik-titik menyebar secara acak tidak membentuk sebuah pola tertentu lainnya. Hal ini menunjukkan model regresi bebas dari Heteroskedastisitas atau dengan kata lain disebut dengan homoskedastisitas.

\section{Regresi Linier Berganda}

Tabel 7. Hasil Uji Analisis Regresi Linier Berganda

\section{Coefficients $^{\mathrm{a}}$}

\begin{tabular}{|c|c|c|c|c|c|c|}
\hline & \multirow{2}{*}{ Model } & \multicolumn{2}{|c|}{ Unstandardized Coefficients } & \multirow{2}{*}{$\begin{array}{c}\text { Standardized } \\
\text { Coefficients } \\
\text { Beta }\end{array}$} & \multirow[t]{2}{*}{$\mathrm{t}$} & \multirow[t]{2}{*}{ Sig. } \\
\hline & & B & Std. Error & & & \\
\hline \multirow[t]{6}{*}{1} & (Constant) & 2.253 & 2.195 & & 1.026 & .308 \\
\hline & Persepsi Keadilan & .600 & .068 & .628 & 8.846 & .000 \\
\hline & Pengetahuan Pajak & .193 & .090 & .237 & 2.134 & .003 \\
\hline & Administrasi Pajak & .634 & .191 & .069 & 3.316 & .001 \\
\hline & Manfaat PP No 46 & .468 & .071 & .511 & 7.326 & .000 \\
\hline & Sosialisasi dan Sanksi & .310 & .081 & .312 & 3.842 & .000 \\
\hline
\end{tabular}

a. Dependent Variable: Kepatuhan Wajib Pajak

Sumber : Pengolahan Data Dengan Program SPSS 23.00

Persamaan regresi :

Kepatuhan Wajib Pajak $=2,253+0,600$ X1 + 0.193 X2 + 0.634 X3 + 0.468 X4 + 0.310 X5+€, hasilnya sebagai berikut:

1. Pada model regresi ini, nilai konstanta sebesar 2.253 yang berarti tanda positif menunjukkan perubahan yang searah. Artinya jika variabel persepsi keadilan (X1), pengetahuan pajak (X2), administrasi pajak (X3), manfaat PP No. 46 (X4) dan sosialisasi dan sanksi (X5) nilainya adalah nol, maka variabel kepatuhan Wajib Pajak adalah sebesar 2.253 satuan. 
2. Indikator dari variabel persepsi keadilan (X1) memiliki nilai koefisien regresi sebesar 0.600 berarti bahwa setiap kenaikan variabel persepsi keadilan (X1) satu satuan maka variabel kepatuhan Wajib Pajak (Y) akan naik sebesar 0.600 dengan asumsi bahwa variabel bebas yang lain dari model regresi adalah tetap.

3. Nilai koefisien pengetahuan pajak (X2) sebesar 0.193. Dapat diartikan bahwa variabel pengetahun pajak (X2) berpengaruh positif terhadap kepatuhan Wajib Pajak (Y). Hal ini menunjukkan bahwa variabel pengetahun pajak (X2) meningkat sebesar satu satuan maka variabel kepatuhan Wajib Pajak (Y) akan mengalami peningkatan sebesar 0.193 satuan.

4. Nilai koefisien administrasi pajak (X3) sebesar 0.634. Dapat diartikan bahwa variabel administrasi pajak (X3) berpengaruh positif terhadap kepatuhan wajib pajak (Y). Hal ini menunjukkan bahwa variabel administrasi pajak (X3) meningkat sebesar satu satuan maka variabel kepatuhan Wajib Pajak (Y) akan mengalami peningkatan sebesar 0.634 satuan.

5. Indikator dari variabel manfaat PP No. 46 (X4) memiliki nilai koefisien regresi sebesar 0.468 berarti bahwa setiap kenaikan variabel manfaat PP No. 46 (X1) satu satuan maka variabel kepatuhan Wajib Pajak (Y) akan naik sebesar 0.468 dengan asumsi bahwa variabel bebas yang lain dari model regresi adalah tetap.

6. Indikator dari variabel sosialisasi dan sanksi (X5) memiliki nilai koefisien regresi sebesar 0.310 berarti bahwa setiap kenaikan variabel sosialisasi dan sanksi (X5) satu satuan maka variabel kepatuhan Wajib Pajak (Y) akan naik sebesar 0.310 dengan asumsi bahwa variabel bebas yang lain dari model regresi adalah tetap.

\section{Uji koefisien Determinasi}

Tabel 8. Hasil Uji Koefisien Determinasi Model Summary

\begin{tabular}{lcccc}
\hline Model & $\mathrm{R}$ & $\mathrm{R}$ Square & $\begin{array}{c}\text { Adjusted R } \\
\text { Square }\end{array}$ & $\begin{array}{c}\text { Std. Error of } \\
\text { the Estimate }\end{array}$ \\
\hline 1 & $.798^{\mathrm{a}}$ & .744 & .728 & 1.15455 \\
\hline a. Predictors: (Constant), Sosialisasi dan Sanksi, Persepsi \\
Keadilan, Manfaat PP No 46, Administrasi Pajak, Pengetahuan \\
Pajak
\end{tabular}

Sumber : Pengolahan Data Dengan Program SPSS 23.00

Dari tabel diatas diperoleh koefisien determinasi atau Adjusted $R$ Square adalah 0.728 artinya $53 \%$ variabel terikat yaitu kepatuhan wajib pajak (Y) variasinya dapat dijelaskan oleh variabel persepsi keadilan (X1), pengatuhuan pajak (X2), administrasi pajak (X3), manfaat PP No. 46 (X4) dan variabel sosialisasi dan sanksi (X5), sisanya sebesar $47 \%$ dijelaskan oleh variabel yang tidak dijelaskan dalam penelitian ini.

\section{Pengujian Hipotesis}

Tabel 9. Hasil Uji T Parsial Coefficients $^{\mathrm{a}}$

\begin{tabular}{llccccc}
\hline \multicolumn{1}{c}{ Model } & \multicolumn{2}{c}{ Unstandardized Coefficients } & $\begin{array}{c}\text { Standardized } \\
\text { Coefficients } \\
\text { Beta }\end{array}$ & T & Sig. \\
& $\mathrm{B}$ & Std. Error & & & \\
\hline 1 (Constant) & 2.253 & 2.195 & & 1.026 & .308 \\
& Persepsi Keadilan & .600 & .068 & .628 & 8.846 & .000 \\
Pengetahuan Pajak & .193 & .090 & .237 & 2.134 & .003 \\
Administrasi Pajak & .634 & .191 & .069 & 3.316 & .001 \\
Manfaat PP No 46 & .468 & .071 & .511 & 7.326 & .000 \\
Sosialisasi dan Sanksi & .310 & .081 & .312 & 3.842 & .000 \\
\hline
\end{tabular}

a. Dependent Variable: Kepatuhan Wajib Pajak

Sumber : Pengolahan Data Dengan Program SPSS 23.00 
Hasil Uji T Parsial menunjukan hasil : Pada variabel keadilan sebesar 8.846 lebih besar dari t tabel $(8.846>1.989)$ dengan tingkat signifikasi 0.000 atau lebih kecil dari 0.05, Pada Variabel pengetahuan sebesar 2.134 lebih besar dari t tabel $(2.134>1.989)$ dengan tingkat signifikasi 0.003 atau lebih kecil dari 0.05, Variabel Administrasi pajak menunjukan sebesar 3.316 lebih besar dari t tabel $(3.316>1.989)$ dengan tingkat signifikasi 0.001 atau lebih kecil dari 0.05 , pada variabel manfaat $(7.326>1.989)$ dengan tingkat signifikasi 0.000 atau lebih kecil dari 0.05 , dan variabel sosialisasi dan sanksi $(3.842>1.989)$ dengan tingkat signifikasi 0.000 atau lebih kecil dari 0.05 . Dapat disimpulkan bahwa ada pengaruh yang signifikan antara persepsi keadilan , pengetahuan, administrasi , pengetahuan, manfaat, sosialisasi dan sanksi dengan kepatuhan Wajib Pajak secara parsial

Tabel 9. Hasil Uji F Simultan

\begin{tabular}{llccccc}
\multicolumn{7}{c}{ ANOVA $^{\mathbf{b}}$} \\
\hline \multicolumn{1}{c}{ Model } & Sum of Squares & Df & Mean Square & F & Sig. \\
\hline 1 & Regression & 186.396 & 5 & 37.279 & 27.967 & $.000^{\text {a }}$ \\
& Residual & 106.639 & 80 & 1.333 & & \\
& Total & 293.035 & 85 & & & \\
\hline
\end{tabular}

a. Predictors: (Constant), Sosialisasi dan Sanksi, Persepsi Keadilan, Manfaat PP No 46, Administrasi Pajak, Pengetahuan Pajak

b. Dependent Variable: Kepatuhan Wajib Pajak

Sumber : Pengolahan Data Dengan Program SPSS 23.00

Berdasarkan hasil hipotesa dengan membandingkan $\mathrm{F}$ hitung dengan $\mathrm{F}$ tabel dimana nilai $\mathrm{F}$ hitung > F tabel $(27.967>3.9201)$ atau $0.000<0.05$ maka ho ditolak dan hasil keputusannya adalah ada pengaruh persepsi keadilan (X1), pengetahuan pajak (X2), administrasi pajak (X3), manfaat PP No. 46 (X4) dan variabel sosialisasi dan sanksi (X5) terhadap kepatuhan Wajib Pajak (Y) secara simultan.

\section{PEMBAHASAN}

\section{Interpretasi Hasil Penelitian Dengan Pengujian T Parsial}

a. Interpretasi pengaruh persepsi keadilan (X1) terhadap kepatuhan Wajib Pajak (Y)

Hasil uji hipotesis 1 menyatakan bahwa persepsi keadilan (X1) berpengaruh terhadap kepatuhan Wajib Pajak UMKM. Nilai kontribusi dari uji t parsial adalah t hitung sebesar 8.846 lebih besar dari $t$ tabel $(8.846>1.989)$ dengan tingkat signifikasi 0.000 atau lebih kecil dari 0.05 yang berarti nilai variabel persepsi keadilan sangat kuat dan signifikan. Keadilan perpajakan termasuk kategori sangat baik dengan didukung hasil yang positif. Hal ini dapat disebabkan banyaknya responden yang berpendapat bahwa tarif yang dikenakan pemerintah sudah tepat dan adil. Hasil penelitian ini sesuai dengan hasil penelitian Tiong (2014) yang menyatakan bahwa rata-rata Wajib Pajak berpendapat bahwa pelaksanaan PP No. 46 tahun 2013 sudah cukup adil dilihat dari aspek distribusinya, pemerataan pembangunan infrastruktur atau fasilitas dan kemudahan menjalankan aktivitas perusahaan terkait dengan kebijakan atau regulasi dan birokrasi.

b. Interpretasi pengaruh pengetahuan pajak (X2) terhadap kepatuhan Wajib Pajak (Y)

Pengetahuan pajak adalah informasi pajak yang dapat digunakan Wajib Pajak sebagai dasar untuk bertindak, mengambil keputusan, dan untuk menempuh arah atau strategi tertentu sehubungan dengan pelaksanaan hak dan kewajibannya dibidang perpajakan. Tetapi fenomena yang terjadi pada saat ini yaitu pengetahuan wajib pajak masih kurang karena masih banyak Wajib Pajak yang belum sadar dan peduli pajak, sehingga kepatuhan Wajib Pajak terhadap peraturan perpajakan menjadi rendah selain itu juga kurangnya pengetahuan yang ada tentang pajak dan ketidaktahuan tentang berbagai peraturan pajak yang berlaku. Agar pengetahuan pajak meningkat maka sebaiknya pendidikan tentang pajak dilakukan di usia dini, selain itu adanya sosialisasi tentang pajak yang dilakukan oleh pegawai pajak agar para Wajib Pajak lebih paham dan pengetahuan pajaknya meningkat. 
Hasil dari penelitian ini menunjukkan bahwa pengaruh antara pengetahuan pajak (X2) terhadap kepatuhan wajib pajak (Y) sangat kuat dan signifikan dengan kontribusi t hitung sebesar 2.134 lebih besar dari t tabel $(2.134>1.989)$ dengan tingkat signifikasi 0.003 atau lebih kecil dari 0.05 yang berarti semakin tinggi tingkat pengetahuan pajak, maka semakin tinggi pula kepatuhan Wajib Pajak atau sebaliknya semakin rendah tingkat pengetahuan pajak maka semakin rendah pula tingkat kepatuhan wajib pajak. Dan kesimpulan dari penelitian bahwa keseluruhan Wajib Pajak UMKM yang ada di Pusat Grosir Metro Tanah Abang memiliki pengetahuan tentang Perpajakan yang diatur dalam PP No. 46 tahun 2013. Hal ini didukung dengan beberapa indikator yang memudahkan responden dalam menjawab setiap butir pertanyaan.

c. Interpretasi pengaruh administrasi pajak (X3) terhadap kepatuhan wajib pajak (Y)

Administrasi pajak pelaksanaan PP 46 Tahun 2013 berpengaruh terhadap kepatuhan Wajib Pajak. Hasil penelitian menunjukkan kontribusi dari variabel administrasi pajak (X3) adalah sebesar 3.316 lebih besar dari t tabel $(3.316>1.989)$ dengan tingkat signifikasi 0.001 atau lebih kecil dari 0.05. Hasil tersebut menunjukkan bahwa administrasi pajak sangat berpengaruh positif terhadap kepatuhan wajib pajak. Dengan latar belakang terbitnya kebijakan PP 46 Tahun 2013 adalah penyederhanaan sistem administrasi perpajakan, sehingga konsep yang praktis, mudah dan sistem online akan meningkatkan kepatuhan Wajib Pajak. Atau dengan kata lain pemerintah bertujuan untuk memberikan kemudahan dan penyederhaan aturan perpajakan, mengedukasi masyarakat untuk tertib administrasi, mengedukasi masyarakat untuk transparansi, dan memberikan kesempatan kepada masyarakat untuk berkontribusi dalam penyelenggaraan Negara.

d. Interpretasi pengaruh manfaat pelaksanaan PP No. 46 (X4) terhadap kepatuhan wajib pajak (Y) Hasil uji hipotesis 4 menyatakan bahwa manfaat pelaksanaan PP No. 46 tahun 2013 (X4) sangat berpengaruh terhadap kepatuhan wajib pajak UMKM (Y). Hasil penelitian menunjukkan bahwa $\mathrm{t}$ tabel berdasarkan data di atas nilai dari t hitung sebesar 7.326 lebih besar dari t tabel (7.326 > 1.989) dengan tingkat signifikasi 0.000 atau lebih kecil dari 0.05 . Hal ini dapat disimpulkan bahwa variabel manfaat pelaksanaan PP nomor 46 tahun 2013 cukup baik walaupun kontraprestasi pajak tidak dapat dirasakan secara langsung, tetapi hasil yang diperoleh rakyat berupa fasilitas umum dapat dirasakan oleh seluruh lapisan masyarakat dengan baik atau dengan kata lain rata-rata responden berpendapat bahwa telah memaham timbal balik dari PP No. 46 tahun 2013.

e. Interpretasi pengaruh sosialisasi dan sanksi (X5) terhadap kepatuhan wajib pajak (Y)

Sosialisasi pajak merupakan proses penyampaian informasi mengenai segala sesuatu yang berhubungan dengan perpajakan kepada masyarakat pada umumnya dan Wajib Pajak pada khususnya. Sosialisasi pajak memiliki peranan penting dalam upayanya untuk meningkatkan kepatuhan Wajib Pajak. Karena melalui sosialisasi pajak yang intensif dapat meningkatkan pemahaman Wajib Pajak mengenai semua hal yang berkaitan dengan perpajakan, mencakup fungsi pajak, regulasi, mekanisme, maupun sanksi yang akan didapatkan oleh Wajib Pajak apabila tidak memenuhi kewajiban perpajakannya. Sanksi pajak merupakan jaminan bahwa ketentuan peraturan perundang-undangan perjakan akan dituruti atau ditaati. Dalam penelitian ini ketegasan sosialisasi dan sanksi Pemerintah atas PP 46 Tahun 2013 berpengaruh terhadap kepatuhan Wajib Pajak. Hasil penelitian menunjukkan bahwa kontribusi variabel sosialisasi dan sanksi adalah sebesar t hitung sebesar 3.842 lebih besar dari t tabel $(3.842>1.989)$ dengan tingkat signifikasi 0.000 atau lebih kecil dari 0.05. Hasil tersebut menunjukkan bahwa administrasi pajak sangat berpengaruh positif terhadap kepatuhan Wajib Pajak. Direktorat Jenderal Pajak sudah melakukan sosialisasi dan mempertegas peraturan pelaksanaan PP 46 tahun 2013 dalam upaya memberikan informasi kepada Wajib Pajak meskipun bagi Wajib Pajak masih sangat minim informasi tersebut terkait pelaksanaan PP 46 tahun 2013. Penerbitan PP No.46 Tahun 2013 pada pertengahan tahun 2013, tepatnya di bulan Juli 2013 yang mulai diberlakukan surut di tahun 2013 dalam pelaporan SPT Tahunan.

\section{Interpretasi Hasil Penelitian Dengan Pengujian F Simultan}

Hasil uji hipotesis 6 menyatakan bahwa persepsi keadilan (X1), pengetahuan pajak (X2), administrasi pajak (X3), manfaat PP No. 46 (X4) dan variabel sosialisasi dan sanksi (X5) berpengaruh positif dan signifikan terhadap kepatuhan Wajib Pajak (Y) secara simultan dengan membandingkan $\mathrm{F}$ hitung dengan $\mathrm{F}$ tabel dimana nilai $\mathrm{F}$ hitung $>\mathrm{F}$ tabel $(27.967>3.9201)$ atau $0.000<0.05$ maka ho 
ditolak. Dan jika dilihat dari hasil koefisien determinasi kseleuruhan variabel memiliki nilai Adjusted $R$ Square adalah 0.728 artinya $(0.728 \times 0.728)=0.529$ atau $53 \%$ variabel terikat yaitu kepatuhan Wajib Pajak (Y) variasinya dapat dijelaskan oleh variabel persepsi keadilan (X1), pengatuhuan pajak (X2), administrasi pajak (X3), manfaat PP No. 46 (X4) dan variabel sosialisasi dan sanksi (X5), sisanya sebesar $47 \%$ dijelaskan oleh variabel yang tidak dijelaskan dalam penelitian ini. Dari hasil tersebut di atas dapat disimpulkan bahwa hasil tersebut sesuai dengan teori atribusi dimana sikap Wajib Pajak untuk mematuhi dan mentaati perpajakan dipengaruhi oleh dua faktor yaitu faktor internal dan faktor eksternal. Faktor internal didapat dari pengetahuan pajak dan manfaat dari PP No. 46 tahun 2013 sehingga Wajib Pajak UMKM dapat mematuhi kewajiban perpajakannya. Faktor eksternal didapat dari keadilan perpajakan, pelaksanaan administrasi pajak serta ketegasan dan sanksi perpajakan yang mempengaruhi sikap Wajib Pajak untuk tidak melakukan pelanggaran dan mematuhi kewajiban perpajakannya.

\section{KESIMPULAN DAN SARAN}

\section{Kesimpulan}

Berdasarkan rumusan masalah, hipotesis penelitian dan hasil penelitian yang sudah diuraikan pada bab sebelumnya, maka penulis dapat menarik kesimpulan sebagai berikut:

1. Persepsi keadilan (X1) berpengaruh terhadap kepatuhan wajib pajak UMKM (Y). Dalam penelitian ini, sebagian besar Wajib Pajak UMKM di Pusat Grosir Tanah Abang menyatakan bahwa tarif yang dikenakan pemerintah dalam pelaksanaan PP no 46 Tahun 2013 sudah tepat dan adil.

2. Pengetahuan Wajib Pajak tentang pelaksanaan PP No. 46 tahun 2013 (X2) berpengaruh terhadap kepatuhan Wajib Pajak UMKM (Y). Keseluruhan Wajib Pajak UMKM di Pusat Grosir Tanah Abang memiliki pengetahuan tentang PP no 46 Tahun 2013 berdasarkan hasil kuesioner.

3. Administrasi pajak PP No. 46 tahun 2013 (X3) berpengaruh signifikan terhadap kepatuhan wajib pajak UMKM (Y). Wajib Pajak UMKM di Pusat Grosir Tanah Abang merasakan terbitnya kebijakan PP 46 Tahun 2013, memberikan kemudahan dalam melaksanakan kewajiban membayar dan melaporkan Pajak.

4. Manfaat pelaksanaan PP No. 46 tahun 2013 (X4) sangat berpengaruh terhadap kepatuhan wajib pajak UMKM (Y), Wajib Pajak UMKM di Pusat Grosir Tanah Abang merasakan manfaat dalam tertib administrasi dan meskipun kontraprestasi pajak tidak dapat dirasakan secara langsung, tetapi hasil yang diperoleh berupa fasilitas umum dapat dirasakan dengan baik.

5. Sosialisasi dan sanksi PP No. 46 tahun 2013 (X5) berpengaruh positif terhadap kepatuhan wajib pajak UMKM (Y). Direktorat Jenderal Pajak sudah melakukan sosialisasi peraturan pelaksanaan PP 46 tahun 2013 dalam upaya memberikan informasi kepada Wajib Pajak UMKM di Pusat Grosir Tanah Abang.

6. Persepsi keadilan (X1), pengetahuan pajak (X2), administrasi pajak (X3), manfaat PP No. 46 (X4) dan variabel sosialisasi dan sanksi (X5) berpengaruh positif dan signifikan terhadap kepatuhan wajib pajak (Y), hasil tersebut sesuai dengan teori atribusi dimana sikap Wajib Pajak untuk mematuhi dan mentaati perpajakan dipengaruhi oleh dua faktor yaitu faktor internal dan faktor eksternal. Faktor internal didapat dari pengetahuan pajak dan manfaat dari PP No. 46 tahun 2013 sehingga Wajib Pajak UMKM dapat mematuhi kewajiban perpajakannya. Faktor eksternal didapat dari keadilan perpajakan, pelaksanaan administrasi pajak serta sanksi perpajakan yang mempengaruhi sikap wajib pajak untuk tidak melakukan pelanggaran dan mematuhi kewajiban perpajakannya.

\section{Saran}

Berdasarkan kesimpulan di atas maka penulis memberikan beberapa saran sebagai berikut :

1. Pemerintah (Dirjend Pajak) memberikan penjelasan secara berkala kepada masyarakat (public) mengenai alokasi penggunaan pajak serta menjelaskan dasar berpikir atas proses perhitungan penentuan besarnya tarif pajak dalam meningkatkan persepsi masyarakat terhadap keadilan perpajakan. 
2. Pengenaan tarif sebesar $1 \%$, sebagai dasar pengenaan pajak dan bersifat pajak final mungkin perlu ditinjau ulang dengan memperhatikan kondisi keuangan perusahaan atau jenis usaha dari wajib pajak khususnya UMKM sehingga tidak memberatkan.

3. Pemerintah (Dirjen Pajak) perlunya berupaya melakukan monitoring dan evaluasi di akhir periode supaya tujuan pengenaan pajak terhadap Wajib Pajak dengan omzet $<4,8 \mathrm{M}$ dapat berjalan dengan baik .

4. Dalam melakukan sosialisasi dan sanksi tentang PP No. 46 tahun 2013 sebaiknya pihak regulator melakukan pendekatan secara personal ke Wajib Pajak sehingga tepat sasaran.

5. Pemerintah (Dirjen Pajak ) perlu melakukan survey terhadap pelaku UMKM , sehingga dapat mengetahui secara langsung keinginan, kemampuan dan keadaaan UMKM yang sebenarnya dalam menetapkan kebijakan peraturan.

\section{DAFTAR PUSTAKA}

Abdul Rahman (2010). Panduan Pelaksanaan administrasi Perpajakan untuk Karyawan, Pelaku Bisnis, dan Perusahaan. Bandung: Nuansa.

Abuyamin, Oyok (2010). Perpajakan Pusat dan Daerah. Bandung : Humaniora.

Agus Nugroho Jatmiko (2006). Pengaruh Sikap Wajib Pajak pada Pelaksanaan Sanksi Denda, Pelayanan Fiskus, dan Kesadaran Perpajakan Terhadap Kepatuhan Wajib Pajak Studi Empiris Terhadap Wajib Pajak Orang Pribadi di Kota Semarang. Unisversitas Diponegoro: Tesis Megister Akuntansi.

Ahsan, Bashori dan Elia (2014). Pengaruh Persepsi Atas PP Nomor 46 Tahun 2013 Terhadap Kepatuhan Sukarela Wajib Pajak Yang Memiliki Peredaran Bruto Tertentu Pada Kantor Pelayanan Pajak Pratama Surabaya Rungkut. Jurnal SNA Universitas Airlangga.

Astri (2014). Pengaruh Penerapan Peraturan Pemerintah Nomor 46 Tahun 2013 Terhadap Tingkat Pertumbuhan Wajib Pajak UMKM dan Penerimaan PPh Pasal 4 Ayat 2 (Studi Kasus pada KPP Pratama Malang Selatan). Jurnal Akuntansi Universitas Brawijaya Malang.

Azmi, A A Che dan Kamala A. Perumal (2008). Tax Fairness Dimensions in an Asian Context: The Malaysian Perspective. International Review of Business Research and Paper, Vol 4: 11-19.

BPS (2015). Perkembangan UMKM Periode 2009 - 2012. Diakses tanggal 15 Juni 2015 dari www.bps.go.id.

Carolina (2009). Pengetahuan Pajak. Jakarta : Salemba Empat.

Devano dan Rahayu (2010). Perpajakan: Konsep, Teori dan Isu. Jakarta: Kencana Prenada Media Group.

Dewi (2013). Pengaruh Pengetahuan Pajak dan Sanksi Pajak Terhadap Kepatuhan Wajib Pajak (Survey di Kantor Pelayanan Pajak Pratama Bandung Karees). Jurnal Akuntansi Universitas Padjajaran.

Diana \& Lilis (2014). Perpajakan "Teori dan Peraturan Terkini”. Yogyakarta : ANDI.

Direktorat Jendral Pajak (2014). Peraturan Pemerintah Nomor 46 Tahun 2013. Diakses tanggal 1 Juni 2015 dari http://www.pajak.go.id/

Edison Wazoel Lubua (2014). Influencing Tax Compliance in SMEs through the Use of ICTs. International Journal of Learning, Teaching and Educational Research Vol. 2, No. 1, pp. 8090.

Emmanuel Eragbhe and Kennedy Prince Modugu (2014). Tax Comliance Costs of Small and Medium Scale Enterprises in Nigeria. International Journal of Accounting and Taxation Vol. 2, No. 1, pp. 63-87.

Gading \& Suandy (2014). Pengaruh Persepsi Tentang Peraturan, Pengetahuan dan Persepsi Tentang Manfaat Terhadap Kepatuhan Dalam Melaksanakan PP Nomor 46 Tahun 2013 di Pasar Klewer Solo. Jurnal Akuntansi Universitas Atma Jaya Yogyakarta. 
Gede Putu (2013). Penerapan Akuntansi Pajak Atas PP Nomor 46 Tahun 2013 Tentang PPh Atas Penghasilan Dari Usaha Wajib Pajak Yang Memiliki Peredaran Bruto Tertentu. Jurnal Akuntansi Profesi Universitas Pendidikan Ganesha.

George Giligant and G. Richardson (20050."Perceptions of Tax Fairness and Tax Compliance in Australia and Hongkong - A Preliminary Study"e, Journal of Financial Crime; Aug 2005; 12, 4; Criminal Justice Periodicals pg.331.

Harri (2008). Aspek Keadilan. Jurnal Skripsi Fakultas Ekonomi Universitas Indonesia.

Haula Rosdiana dan Edi Slamet (2011). Pengantar Ilmu Perpajakan Kebijakan dan Implementasi di Indonesia. Jakarta:Grafindo.

I Ketut Yadnyana (2009). Pengaruh Moral dan Sikap Wajib Pajak pada Kepatuhan Wajib Pajak Koperasi di Kota Denpasar. Denpasar: Fakultas Ekonomi Universitas Udayana.

Inasius Fani (2012). Analisis Pajak Penghasilan Bagi Wajib Pajak Badan Usaha Kecil-Menengah Di Indonesia. Binus Business Review Vol. 3 No. 2 November 2012.

Jogiyanto (2013). Metodologi Penelitian Bisnis "Salah Kaprah dan Pengalaman-Pengalaman" (Edisi 6). Yogyakarta : BPFE

KBBI (2015). Persepsi. Diakses 3 Juni 2015 dari http://kbbi.web.id/

Kemenkeu (2015). Sektor-Sektor UMKM. Diakses tanggal 1 Juni 2015 dari www.kemenkeu.go.id

Mardiasmo (2011). Perpajakan. Edisi Revisi.Yogyakarta : ANDI

Moh. Nazir (2005). Metode Penelitian. Bogor : Ghalia.

Oktaviane Lidya Winerungan, 2013. Sosialiasai Perpajakan, Pelayanan Fiskus Dan Sanksi Perpajakan Terhadap Kepatuhan WPOP di KPP Manado dan KPP Bitung. Fakultas Ekonomi dan Bisnis, Jurusan Akuntansi, Universitas Sam Ratulangi Manado. Jurnal Emba Vol.1No.3September 2013, hal 960-970.

Ony, dkk (2008). Pengantar Perpajakan. Bandung : Unikom

Pakde Sofa. (2008). Pengertian Administrasi Perpajakan, Kepatuhan dan Pajak Internasional. www.pajakonline.com.

Pandiangan (2007). Modernisasi Dan Reformasi Pelayanan Perpajakan Berdasarkan UU Terbaru. Jakarta: PT Elek Media Komputindo.

Peluang Usaha (2012). Sejarah Pusat Grosir Tanah Abang. Diakses tanggal 15 Juni dari http://peluangusaha17.blogspot.com/2012/08/sejarah-pusat-grosir-tanah-abang.html

Peraturan Menteri Keuangan Nomor 74/PMK.03/2012 tentang Tata Cara Penetapan dan Pencabutan Penetapan Wajib Pajak dengan Kriteria Tertentu dalam rangka Pengembalian Pendahuluan Kelebihan Pembayaran Pajak.

Pudyatmoko (2009). Pengantar Hukum Pajak. Yogyakarta : Andi

Rivai, Veithzal (2009). Manajemen Sumber Daya Manusia Untuk Perusahaan Dari Teori ke Praktik. Jakarta : Raja Grafindo Persada.

Rosdiana dan Tarigan (2005). Perpajakan. Teori dan Aplikasi. Jakarta: PT. Raja Grafindo Persada.

Saad, Natrah (2009). Fairness Perceptions and Compliance Behaviour: The Case of Salaried Taxpayers in Malaysia after Implementation of the SelfAssessment System. eJournal of Tax Research, Vol.8 No.1: p 32-63.

Samudera (2005). Perpajakan di Indonesia, Keuangan, Pajak, dan Retribusi. Jakarta : Hecca Publising

Santoso. (2013). SPSS Versi 23. Mengelola Data Statistik. Jakarta : Elex Media Komputindo. 
Simon James and Clinton Alley (2002). Tax Compliance, Self Assessment Tax Administration. Munich Personal RePEc Archive

Siti Kurnia Rahayu (2010). Perpajakan Indonesia Konsep dan Aspek Formal. Yogyakarta: Graha Ilmu.

Suartana \& Robbin (2008). Akuntansi Keperilakuan : Teori dan Implementasi. Yogyakarta : Andi.

Sue Young and Nthati Rametse (2010). The Influencing of Procedural fairness on the Small Business Entrepreneurs and Their Perception of the Tax Authority : A Case Study Approach. International Review of Business Research Papers Vol. 6, No. 1, pp. 487-512.

Sugiyono (2009). Metode Penelitian Bisnis. Bandung : Alfabeta. (2010). Metode Penelitian Bisnis. Bandung : Alfabeta. (2014). Metode Penelitian Bisnis. Bandung : Alfabeta.

Susmiatun (2014). Pengaruh Pengetahuan Perpajakan, Ketegasan Sanksi Perpajakan dan Keadilan Perpajakan Terhadap Kepatuhan Wajib Pajak UMKM Di Kota Semarang. Accounting Analysis Journal. 3(1) Agustus 2014. ISSN 2252-6765.

Suyapto (2013). Faktor-Faktor Yang Mempengaruhi Kepatuhan Wajib Pajak. Jurnal Tesis Universitas Airlangga.

Tiong (2014). Pengaruh Pelaksanaan PP No. 46 Tahun 2013 Terhadap Kepatuhan Wajib Pajak UMKM (Studi Kasus UMKM di Wilayah DKI Jakarta Mega Glodok Kemayoran. Jurnal Tesis Universitas Mercu Buana.

Umar, Husein (2013). Metode Penelitian Untuk Skripsi dan Tesis Bisnis (Edisi Kedua). Jakarta : Raja Grafindo.

Vadde \& Gundarapu (2012). Factors That Influence Rental Tax Payers Compliance With Tax System: An Empirical Study of Mekelle City, Ethiopia. Journal of Arts, Science \& Commerce Vol III, Issue 4 (2) Oktober 2012. ISSN 2231-4172.

Yudhistira (2010). Peranan UMKM dan Permasalahan UMKM. Diakses 15 Juni 2015 dari https://yudhislibra.wordpress.com/2010/11/22/64/

Yuni (2014). Penerapan PP Nomor 46 Tahun 2013 Pada UMKM (Studi Kasus Pada CV. Lestari Malang). Jurnal Akuntansi Universitas Brawijaya Malang 